\title{
Group A rotavirus genotypes and the ongoing Brazilian experience - A Review
}

\author{
José Paulo Gagliardi Leite/ ${ }^{+}$, Filipe Anibal Carvalho-Costa', Alexandre C Linhares ${ }^{2}$ \\ Laboratório de Virologia Comparada, Instituto Oswaldo Cruz-Fiocruz, Av. Brasil 4365, 21045-900 Rio de Janeiro, RJ, Brasil 'Laboratório \\ de Sistemática Bioquímica, Instituto Oswaldo Cruz-Fiocruz, Rio de Janeiro, RJ, Brasil ${ }^{2}$ Instituto Evandro Chagas, Secretaria de Vigilância \\ em Saúde, Belém, PA, Brasil
}

Brazil was the first Latin American country to introduce universal group A rotavirus (RV-A) vaccination in March 2006, resulting in a unique epidemiological scenario. Since RV-A first identification in Brazil, 2,691 RV-A-positive stool samples, collected between 1982-2007, were typed by independent research groups throughout the country. In the prevaccination era, 2,492 RV-A-positive samples collected from 1982-2005 were successfully typed, while 199 samples were analyzed from 2006-2007. According to the reviewed studies, there were two important times in the pre-vaccination era: (i) the period from 1982-1995, during which the detection of G5P[8] RV-A, in addition to the classical genotypes G1-4, challenged vaccine development programs; and (ii) the period from 1996-2005, during which genotype G9P [8] emerged, following a global trend. The rate of G2P [4] RV-A detection decreased from 26\% (173/653) during 1982-1995 to $2 \%(43 / 1,839)$ during 1996-2005. The overall detection rate of $R V-A$ genotypes from 1982-2005 was as follows: $43 \%(n=1,079) G 1 P[8] / G 1 P[$ not typed (NT)]; $20 \%(n=488) G 9 P[8] / G 9 P[N T] ; 9 \%(n=216) G 2 P[4] / G 2 P[N T] ; 6 \%$ $(n=151) G 3 P[8] / G 3 P[N T] ; 4 \%(n=103) G 4 P[8] / G 4 P[N T] ;$ and $4 \%(n=94) G 5 P[8] / G 5 P[N T]$. Mixed infections accounted for 189 (7\%) of the positive samples, while atypical G/P combinations or other genotypes, including G6, G8, G10 and G12, were identified in 172 (7\%) samples. The initial surveillance studies carried out in several Brazilian states with RV-A-positive samples collected in 2006 and 2007 show a predominance of G2P[4] strains (148/199 or 74\%). Herein, we review RV-A typing studies carried out since the 1980s in Brazil, highlighting the dynamics of RV-A strain circulation profiles before and early after universal use of $R V-A$ vaccine in Brazil.

Key words: rotavirus - genotypes - vaccine - Brazil

Rotavirus is a genus of the Reoviridae family. The rotavirion, which is non-enveloped, has a triple layer capsid structure that surrounds a genome composed of 11 segments of double-stranded RNA (dsRNA). Each of the six structural (VP1-4, VP6-7) and six non-structural proteins (NSP1-6) is encoded in a unique genome segment, with the exceptions of NSP5 and NSP6, which are encoded in overlapping reading frames of segment 11. Rotaviruses have seven major groups (A-G); most human strains belong to group A (RV-A), although groups $\mathrm{B}$ and $\mathrm{C}$ have been associated with human illness (Estes 2007). Among RV-A isolates, distinct serotypes [as determined by serological assays using monoclonal antibodies (MAbs)] and genotypes (as defined by molecular analyses of the viral RNA) can be recognized. Since the majority of RV-A typing studies have been carried out using polymerase chain reaction (PCR), we discuss the variability of genotype, rather than serotype, in this paper. The antigens that define the RV-A genotype include the two structural proteins that make up the outer capsid of the virion, VP4 and VP7 (Kapikian et al. 2003).

Financial support: IOC-FIOCRUZ, Instituto Evandro Chagas/SVS/ $\mathrm{MS}, \mathrm{CNPq}$

+ Corresponding author: jpgleite@ioc.fiocruz.br

Received 11 December 2008

Accepted 16 December 2008
These proteins induce the production of neutralizing antibodies during the course of an infection. As two antigens define the genotype, the genotypic designation has two components. The genotypic characteristic given by VP7 is specified as the G genotype since VP7 is a glycoprotein. Similarly, the genotypic characteristic given by VP4 is specified as the P genotype because this protein exhibits protease-sensitivity. Up to now, at least $19 \mathrm{G}$ genotypes and $27 \mathrm{P}$ genotypes have been described (Ciarlet et al. 2008). Theoretically, many G/P combinations are possible within the binary system utilized to classify RV-A genotypes; however, the G1P[8], G2P[4], G3P[8], G4P[8] and G9P[8] combinations are the most commonly identified genotypes worldwide (Castello et al. 2004, Gentsch et al. 2005, Santos \& Hoshino 2005a, Gurgel et al. 2008).

In addition to the $\mathrm{G}$ and $\mathrm{P}$ genotypes, the serology of VP6 is used to classify RV-A into subgroups (SG) I, II, I+II and non-I and non-II, which are defined according to the presence or absence of two distinct epitopes that are reactive with one, both or neither of the MAbs 255/60 and $631 / 9$. The SG specificities are determined by amino acids located at positions 305 , the region between amino acids positions 296 and 299 (SGI) and amino acid position 315 (SGII) (López et al. 1994, Tang et al. 1997). Many epidemiological studies have used subgrouping enzyme immunoassays (EIAs). Based upon these analyses, most human isolates fall into SGII (Arista et al. 1990, Gómara et al. 2001), while most animal isolates fall into SGI (Tang et al. 1997). 
Diarrheal diseases remain a major public health concern, representing the second most important cause of child mortality in developing countries (Boschi-Pinto et al. 2008). RV-A is one of the most prevalent pathogens associated with infantile gastroenteritis, being responsible, on a global scale, for nearly 611,000 deaths per year (Parashar et al. 2006).

In Brazil, proportional mortality by acute diarrhea in children less than five years old presents significant variation by geographic region, as it is higher in the Northeastern and Northern regions (MS 2006). These rates, on a national scale, present a decreasing trend over time. Between 1990-2004, for example, the proportional mortality associated with diarrheal diseases was reduced from $11 \%$ to $4 \%$ (MS 2006) (Fig. 1).

It is difficult to estimate the proportion of infantile gastroenteritis associated-deaths that are caused by RVA. An estimated rate of $40 \%$ has been reported; this rate varies according to the sanitation background. Barnes et al. (1998) reported a rate of RV-A infection of $39.6 \%$ among 3,785 hospitalized children with gastroenteritis between 1980-1993 in Australia. It has been demonstrated that the majority of RV-A gastroenteritis deaths occur in developing countries (Miller \& McCann 2000). In Brazil, gastroenteritis mortality data time series analysis indicated that deaths peak during winter, which suggests that RV-As play an important role in this context (Kale et al. 2004). In line with these data, a recent analysis of WHO surveillance network data for 2001-2008 indicated that approximately $40 \%$ of diarrhea-related hospitalizations among children aged $<5$ years worldwide are attributable to RV-A infection (CDC 2008). Such a substantial worldwide burden of RV-A diarrhea indicates a significant potential health impact of vaccination. Other important viral pathogens causing acute diarrhea in children include noroviruses, astroviruses and enteric adenoviruses (Victoria et al. 2007a, b, Magalhães et al. 2007, Andreasi et al. 2008).

Longitudinal studies have shown that naturally acquired RV-A infections confer protection against subsequent severe RV-A diarrheic episodes (Bernstein et al. 1991, Ward \& Bernstein 1994, Moulton et al. 1998).

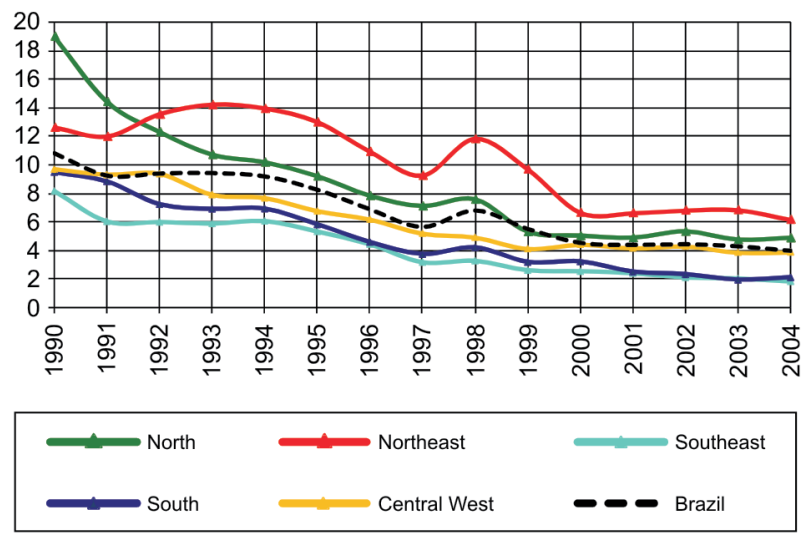

Fig. 1: diarrheal diseases proportional mortality (\%) in children under five years old from 1990-2004 in distinct Brazilian regions.
Asymptomatic infection of newborns has also been shown to reduce the likelihood of developing severe RVA-gastroenteritis during childhood (Bishop et al. 1983, Bhan et al. 1993). Surveys carried out in Mexico show that protection increases with successive reinfections and that surveyed children did not develop RV-A gastroenteritis after two RV-A infections (Velazquez et al. 1996). These findings encouraged the development of RV-A vaccines.

Transmission of most enteropathogens that are transmitted through the faecal/oral route can be interrupted by improving sanitation conditions and improving access to a safe water supply. RV-A gastroenteritis affects children in both developed and developing countries, which have distinct socioeconomic environments. For this reason, RV-A transmission cannot be mitigated by improvements in sanitation and improved access to a safe water supply. Therefore, an effective vaccine constitutes the only possible means of preventing transmission of RV-A diarrhea (Glass et al. 2006).

Several RV-A vaccine strategies have been attempted over the past two decades (Dennehy 2008). The recently developed live and attenuated G1P[8] RV-A vaccine Rotarix (GlaxoSmithKline, Rixensart, Belgium) was introduced into the Brazilian Expanded Immunization Program in March 2006. In 2008, the national vaccination coverage was $89.9 \%$ for the first dose and $76.4 \%$ for the second dose.

A phase III Rotarix trial was carried out in twelve countries (Argentina, Brazil, Chile, Colombia, Dominican Republic, Honduras, Mexico, Nicaragua, Panama, Peru, Venezuela and Finland). The trial included 63,225 children for safety and 20,169 children for efficacy assessment (Ruiz-Palacios et al. 2006). This one-year follow-up trial showed efficacy against severe RV-A gastroenteritis (Vesikari score > 11) of 92\% for the G1P[8] genotype and of $87 \%$ for pooled G9P[8], G3P[8] and G4P[8] genotypes. Efficacy against the fully heterotypic G2P[4] RV-A was $41 \%$, but circulation of this genotype was low during the study, which impaired a conclusive type-specific efficacy assessment. With an extended follow-up period, including children up to two years of age in Latin America (Linhares et al. 2008), a phase III trial confirmed vaccine efficacy, in spite of a lower protection achieved against G2P[4] RV-A of 43.8\%. Nevertheless, circulation of G2P[4] RV-A strains, which do not share the VP7 or VP4 surface antigen with the vaccine strain, was very low. This strain was detected in five vaccinated infants and in eight unvaccinated control recipients. A European Rotarix phase III trial was carried out in six countries (Czech Republic, Finland, France, Germany, Italy and Spain) (Vesikari et al. 2007). These studies demonstrated cross-protection against severe G2P[4] RV-A gastroenteritis (efficacy $=85.5 \%$; 95\% CI =24-98.5) (Vesikari et al. 2007).

The objective of this review is to describe the distribution of RV-A genotypes in five Brazilian regions from 1982-2007. We aim to provide a general overview of the changing trends in the detection rates of distinct RV-A genotypes by reviewing data available for this period, stratified by geographic region. This analysis allows for a comparison of rates for the pre and early post-vaccination periods. 
A literature review on rotavirus serotyping and genotyping in Brazil identified 42 articles describing RV-A detection and typing of 2,691 stool samples collected from 1982-2007. Among these surveys, 16 (39\%) were carried out in the Southeast (states of Rio de Janeiro, São Paulo, Minas Gerais and Espírito Santo), seven (17\%) in the North (state of Pará), seven (17\%) in the Northeast (states of Bahia, Maranhão, Sergipe, Pernambuco, and Piauí), five $(12 \%)$ in the Central-West (states of Goiás and Mato Grosso do Sul) and one (3\%) in the South (state of Paraná) of Brazil. One study (3\%) was carried out in several regions (states of Pernambuco, Alagoas, Bahia, Minas Gerais, Rio de Janeiro, São Paulo, Goiás, Paraná and Santa Catarina) and Federal District throughout the country.

The pre-vaccination era (1982-2005) was divided in two periods. The first period included $653 \mathrm{RV}-\mathrm{A}$-positive samples that were collected from 1982-1995; these cases were reported in 15 papers in our literature review (Linhares et al. 1988, 1993, Stewien et al. 1994, De Castro et al. 1994, Gouvea et al. 1994, Timenetsky et al. 1994, Gusmão et al. 1995, 1999, Leite et al. 1996, Mascarenhas et al. 1998, 1999, 2002, Cardoso et al. 2000, 2001, Carmona et al. 2004). The second period included 1,839 RV-A-positive samples that were collected from 19962005; these cases were reported in 19 articles in our literature review (Santos et al. 1998, 2003, 2005b, Araújo et al. 2002, Rosa-e-Silva et al. 2002, Souza et al. 2003, Costa et al. 2004, Luz et al. 2005, Carmona et al. 2006, Carvalho-Costa et al. 2006, 2009, Pietruchinski et al. 2006, Volotão et al. 2006, Andreasi et al. 2007, Gouvea et al. 2007, Montenegro et al. 2007, Martini et al. 2008, Domingues et al. 2008, Ribeiro et al. 2008). Altogether, during the pre-vaccination era, 2,492 RV-A-positive faecal samples were typed, either by use of monoclonal antibody or PCR assays. Only one paper in our review describes genotyping of RV-A-positive samples collected from 1994-1996 (i.e., during both defined periods), without specifying the results by year; therefore, this article has been reviewed separately (Macedo et al. 2007). Finally, seven papers report 199 RV-A-positive samples that were collected after introduction of universal RV-A vaccination (2006-2007) (Araújo et al. 2007a, Gouvea et al. 2007, Gurgel et al. 2007, Nakagomi et al. 2008, Domingues et al. 2008, Ribeiro et al. 2008, CarvalhoCosta et al. 2009). From these, five papers included samples collected before 2006, which were categorized as belonging to the pre-vaccination era.

We opted not to include RV-A G5P[8] in the category of atypical genotypes, since it was frequently detected in stool samples collected in the 1980s and early 1990s in Brazil. The following genotypes were considered atypical: VP7 genotypes G6, G8, G10 and G12 and unusual $\mathrm{G} / \mathrm{P}$ combinations distinct from G1P[8], G2P[4], G3P[8], G4P[8], G5P[8] or G9P[8]. Our analysis excluded untyped and only VP4-typed samples.

Fig. 2 presents the RV-A genotypes that were identified across geographic regions during the pre-vaccination era (1982-2005). Fig. 3 shows the nationwide detection rates of RV-A genotypes in the following three periods: 1982-1995, 1996-2005 and 2006-2007. The latter period corresponds to the early post-vaccination era.
The overall detection rate of RV-A genotypes from 1982-2005 was as follows: 43\% $(\mathrm{n}=1,079) \mathrm{G} 1 \mathrm{P}[8] /$ G1P[not typed (NT)]; 20\% $(\mathrm{n}=488)$ G9P[8]/G9P[NT]; $9 \%(\mathrm{n}=216)$ G2P[4]/G2P[NT]; 6\% $(\mathrm{n}=151) \mathrm{G} 3 \mathrm{P}[8] /$ G3P[NT]; 4\% $(\mathrm{n}=103)$ G4P [8]/G4P[NT] and 4\% $(\mathrm{n}=$ 94) G5P[8]/G5P[NT]. Mixed infections accounted for $189(7 \%)$ of the positive samples, while atypical G/P combinations or other genotypes were identified in 172 samples (7\%). In addition to the predominance of G1 RV-As, there were four main findings in this period: (i) G5P [8] genotype was detected, almost exclusively, from the 1980s-1995/1996. During this period, this genotype was identified in $9 \%$ of the analyzed RV-A-positivestool samples. We found that this genotype was present in nine states (Alagoas, Bahia, Goiás, Pará, Paraná, Pernambuco, Piauí, Rio de Janeiro and São Paulo) and in the Federal District; (ii) G9P[8] was reported from 1996 onwards and, during the period of 1996-2005, it was detected in $27 \%(488 / 1,839)$ of RV-A samples, showing a broad geographic distribution; (iii) The detection rate of G2P[4] RV-A decreased from 26\% (173/653) in the period of $1982-1995$ to $2 \%(43 / 1,839)$ in the period of $1996-$ 2005; (iv) Many strains (14\%) exhibited mixed, other G genotypes, or unusual $\mathrm{G} / \mathrm{P}$ combinations. Among the non-G1-G5/G9 VP7 genotypes described above, the following detected strains deserve attention: (i) G8 (including G8P[4]) and G10 (including G10P[9]) in Rio de Janeiro and in Northeastern Brazil; (ii) G12P[9] in state of Paraná; (iii) G3P[4], which caused an outbreak of RV-A gastroenteritis in state of Minas Gerais; and (iv) G6 RVAs in state of São Paulo.

Taken together, these findings underscore the broad diversity of RV-A genotypes in Brazil. The substitution of G5 by G9 RV-As from 1996 onwards motivated us to choose this year to separate two periods in the pre-vaccination era.

In reviewing the eight papers that describe the distribution of RV-A genotypes following introduction of $\mathrm{RV}-\mathrm{A}$ vaccine in Brazil, we observed a significant predominance of G2P[4] and G2P[NT] strains. G2 RV-As were detected in 148 (74\%) out of 199 tested RV-A-positive samples. This genotype was followed by G1, G3 and G9 RV-As, which accounted for 3\%, 3\% and $11 \%$ of the faecal samples, respectively. In this period, mixed and atypical genotypes accounted for $8 \%$ of the typed samples. From 2006-2007, G2 RV-As were detected in the states of Rio de Janeiro, Sergipe, Pernambuco, Piauí and Minas Gerais. A recent preliminary analysis indicates the re-emergence of G2 RV-A strains in Northern Brazil, yielding rates of up to $90 \%$ of all RV-A isolates as from early 2006 (de Oliveira et al. 2008).

Characterization of genotypes in children with RV-A diarrhea has been considered strategic by the World Health Organization (WHO) in order to plan for the introduction of RV-A vaccines (WHO 2002). They have emphasized the need for previous knowledge of the prevalence of RV-A genotypes in various geographic settings where a RV-A vaccine will be introduced. Moreover, WHO strongly recommends the performance of strain surveillance to monitor circulating RV-A strain diversity and possible strain replacement following the introduction of universal RV-A vaccination (CDC 2007). 


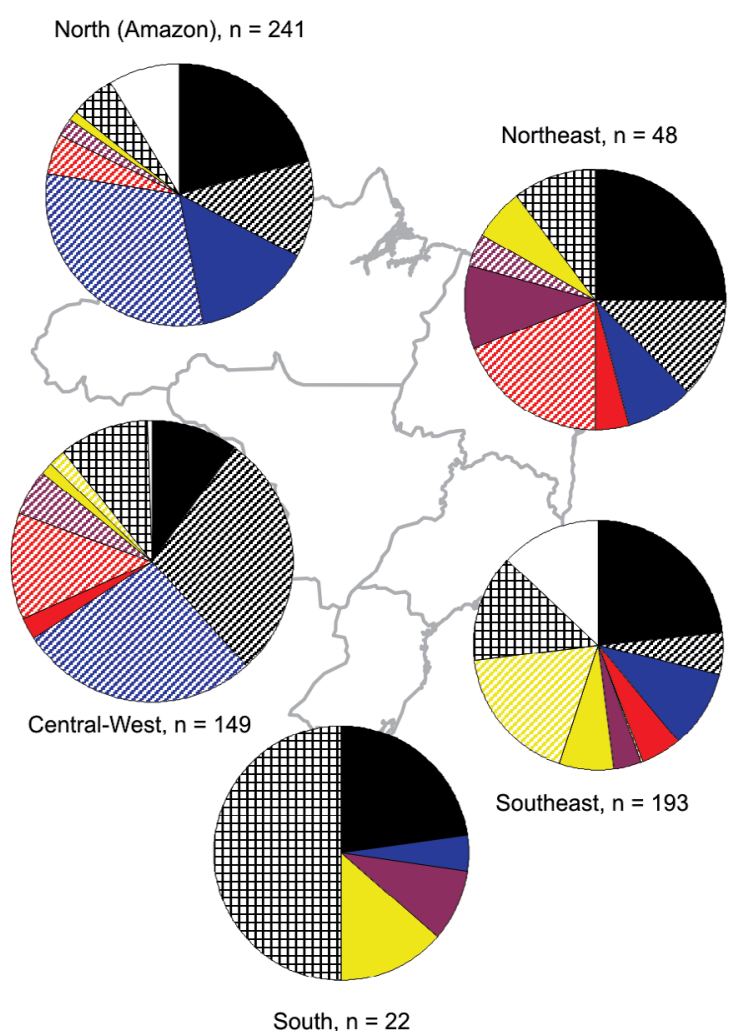

A

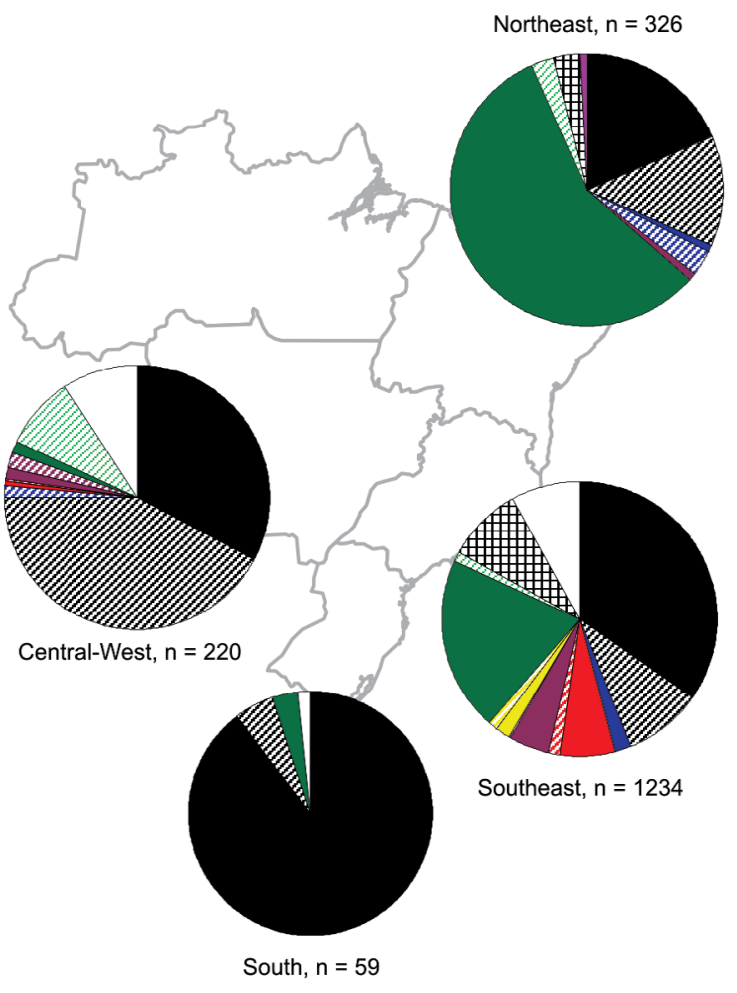

B

\begin{tabular}{|c|c|c|c|c|c|c|}
\hline G1P[8] & $\approx \mathrm{G} 1 \mathrm{P}[\mathrm{NT}]$ & $\square \mathrm{G} 2 \mathrm{P}[4]$ & $\because \mathrm{G} 2 \mathrm{P}[\mathrm{NT}]$ & — G3P[8] & $\because \mathrm{G} 3 \mathrm{P}[\mathrm{NT}]$ & $\square$ G4P[8] \\
\hline 0 & & $\mathrm{G}$ & $\mathrm{P}[\mathrm{\varepsilon}$ & $\mathrm{P}[\mathrm{NT}]$ & mix & \\
\hline
\end{tabular}

Fig. 2: rotavirus genotypes in Brazil by geographic region. A: 1982-1995 (653 positive stool samples); B: 1996-2005 (1,839 positive stool samples).

The recently developed RV-A vaccines are based on distinct vaccination strategies. The monovalent G1P[8] vaccine Rotarix, which was introduced in Brazil in March 2006, was based on the principle that natural RV-A infections induce significant cross-protection (heterotypic immunity) against severe gastroenteritis regardless of the infecting serotype (Velázquez et al. 1996). It should be noted that the VP4 epitopes present in genotype $\mathrm{P}[8]$ are usually shared by G1, G3, G4 and G9 RV-A strains, which should confer VP4-homotypic protection. Therefore, in regard to the antigenic composition of Rotarix, the only fully heterotypic RV-A genotype is G2P [4], which shares neither VP7 nor VP4 antigens with the vaccine strain. Nonetheless, it is believed that protection against $\mathrm{G} 2 \mathrm{P}[4]$ is achieved through cross-reactive epitopes on VP7 and VP4 proteins, together with VP6 epitopes and possibly epitopes on NSP (Grimwood \& Kirkwood 2008).

The nature of the immune response to RV-A infection is not completely understood. Although the immune response to RV-A is not the focus of this paper, we identified multiple studies that aimed to characterize RV-A genotypes responsible for sequential RV-A infections. More specifically, we identified 12 prospective cohort surveys carried out in 10 countries (Fontayne et al. 1978, Gurwith et al. 1981, Bishop et al. 1983, Friedman et al. 1988, Georges-Courbot et al. 1988, Linhares et al. 1988, Reves et al. 1989, Bernstein et al. 1991, Bhan et al. 1993, Ward \& Bernstein 1994, Velázquez et al. 1996, Moulton et al. 1998). Altogether, these studies included 2,031 infants, aged 1-24 months, who were followed for periods varying from 12-36 months. Among this population, 306 subjects developed sequential RV-A infections. The first and second RV-A-positive stool samples were typed for only 32 subjects. Twenty-six (81\%) of the subjects were reinfected with a genotype that was distinct from that responsible for the first infection. These small numbers illustrate the difficulty in understand the natural history of RV-A sequential infections and, consequently, the immune response against this pathogen. 


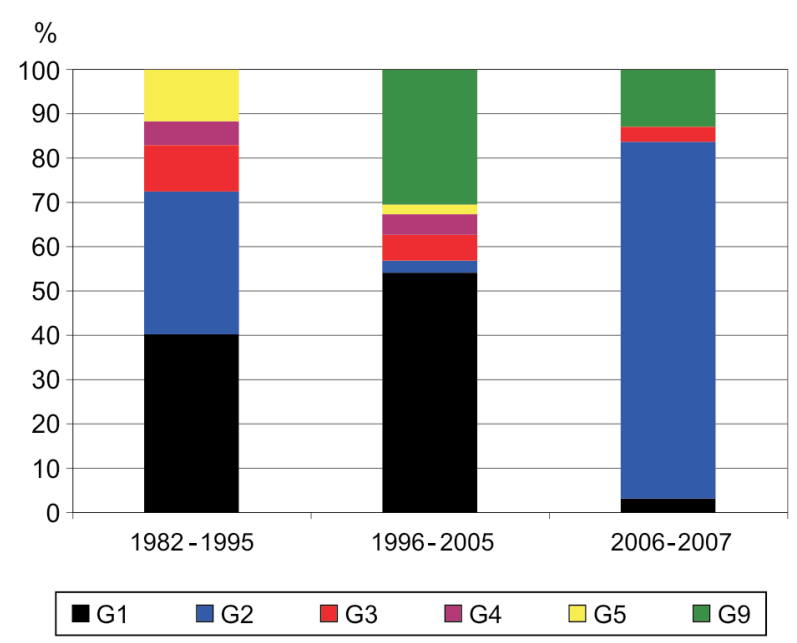

Fig. 3: rates of identification of group A rotaviruses G-genotypes in distinct periods in Brazil.

Uncommon or emergent RV-A genoytpes, which are found mainly in developing countries, trigger discussions about the potential efficacy, in some regions, of the vaccines that were undergoing clinical trials during the early 1990s (Leite et al. 1996, Gouvea \& Santos 1999). The rationale for the development of the rhesus-human tetravalent reassortant vaccine (RRV-A-TV, Rotashield ${ }^{\mathrm{TM}}$ ), for instance, was that its multivalent composition would target the classical genotypes G1-4. This vaccine was licensed for use in the United States in 1998. The epidemiological importance of G5P[8] RV-A in the 1980 s and early 1990 s was seen as a potential challenge to the applicability of this vaccine in Brazil. Rotashield $^{\mathrm{TM}}$ was withdrawn from the United States immunization schedule due to an identified association with intestinal intussusception (CDC 1999). Detection of G5 RV-A in many developing countries (Santos \& Hoshino 2005a) was probably the first demonstration that nonG1-4 RV-A could be present under endemic or epidemic backgrounds, offering new insights in RV-A vaccination planning and vaccine design. As previously indicated, G5 RV-A was identified in all Brazilian regions, displaying a broad nationwide distribution over at least 14 years. Interestingly, G5 RV-A has disappeared as an endemic/ epidemic strain, as it has been only sporadically detected from 1996 onwards.

The analysis of the $42 \mathrm{RV}-\mathrm{A}$ typing surveys published in Brazil since 1988, which include samples collected as early as 1982, allows for outlining of two temporal "scenarios" within the pre-vaccination era, up to 2005 . We postulate that such periods might be differentiated by the sharp decline in rates of G5 detection, which coincided with the emergence of G9 RV-As; the latter strains were initially detected in samples collected in 1997 in the state of Rio de Janeiro (Araújo et al. 2001, Santos et al. 2001). RV-As belonging to genotype $\mathrm{G} 9$ then emerged worldwide in the 1990s. This genotype was subsequent- ly recognized as being highly prevalent in many areas. The study published by Macedo et al. (2007) describes the genotyping of samples collected from 1994-1996 in state of Piauí (Northeastern Brazil). It demonstrates the co-circulation of G5 and G9 RV-A genotypes, but does not specify the year in which the samples were collected. Interestingly, these authors postulate the possibility that G9 was circulating before 1997.

Interestingly, 129 out of 199 RV-A-positive samples collected from 2006-2007 in Brazil were characterized as either G2P[4] or G2P[NT]. These studies were carried out in states of Espírito Santo, Minas Gerais, Pernambuco, Piauí, Rio de Janeiro and Sergipe, suggesting a broad reemergence of this genotype nationwide. Some samples that were characterized as G2P[4] were collected very soon after the introduction of the RV-A vaccine, during the first half of 2006. Of note, many children included in these studies were not eligible for full RV-A vaccination, since they were born before January 2006. We argue that, in those months, with a limited cohort of fully vaccinated infants, G2P[4] reemergence was probably not associated with RV-A vaccination.

The remarkable reemergence of G2P[4] RV-A during the last few years seems to reflect a continental phenomenon. In this context, a recent epidemic of RV-A diarrhea, with a high incidence of the G2P[4] genotype, was reported in Honduras (Ferrera et al. 2007). Ongoing surveillance in El Salvador, Guatemala and Honduras demonstrated that G2P[4] was the most prevalent genotype in 2006 (68-81\%) (Patel et al. 2008). Moreover, the G2P[4] genotype was detected to be circulating in Argentina (J Stupka, personal communication) during the last two years. In Paraguay, RV-As characterized as G2P[4] were frequently detected in 2005 , following a long period (6 years) of its absence (Amarilla et al. 2007). It is worth mentioning that these South-American countries bordering Brazil had not yet introduced RV-A vaccination into the public sector and that increased detection of G2P[4] occurred prior to the implementation of Rotarix vaccination in Brazil.

Interestingly, outside of Latin America, the rates of G2P[4] RV-A detection have recently increased in Bangladesh (43\% in 2005-2006) (Rahman et al. 2007).

Bishop et al. (1991) serotyped 690 RV-A strains collected between 1973-1989 from 943 children admitted with acute diarrhea to a hospital in Melbourne, Australia. They reported interesting findings concerning the seasonal variability of RV-A genotypes: (i) whenever present, G2 RV-As were largely predominant in the epidemiological scenario and this pattern prevailed across three successive seasons; (ii) reemergence of G2 strains tends to occur in 10year cycles. Extensive and continuous RV-A surveillance studies aiming to assess the pattern of temporal fluctuation in the prevalence rates of RV-A genotypes have not yet been conducted in Brazil. Our current review aims to shed light on this issue by reviewing a representative number of Brazilian RV-A typing studies published from 1988-2007. Herein, we corroborate, to some extent, the findings of Bishop et al. (1991) as we demonstrate a 10-year interval between the decrease in G2 RV-A detection observed after 1996 and its subsequent reemergence in 2006. 
In light of the above-mentioned findings, some questions emerge regarding the early post-vaccination era. Did RV-A vaccination finish a cycle in RV-A epidemiology in Brazil? If so, to what extent did the monovalent RV-A vaccine contribute to the observed marked shift in genotype distribution? Are the circulating G2 RV-As merely "residual" strains in the context of a remarkable decrease in the rates of RV-A detection in children with gastroenteritis? To that end, will the "residual" strains disappear following a natural fluctuation pattern? Did the continental spread of G2P[4] RV-A affect Brazil because it was a "fertile land" in which a large proportion of children were protected against $\mathrm{P}[8]$ strains?

According to Grimwood and Kirkwood (2008), it is too early to answer such questions. We believe that extensive simultaneous multi-centre surveillance studies with well-designed case-control studies are urgently needed in order to better assess post-vaccination issues such as: (i) the rate of RV-A detection in hospitalized children with gastroenteritis; (ii) the rate of distinct genotypes detection in RV-A-positive children. These strategies are expected to guide and improve future immunization policies.

\section{Future prospects on RV surveillance}

Phylogenetic studies of RV-A obtained from different countries have characterized the presence of distinct lineages and sub-lineages of many common genotypes, including G9 (Hoshino et al. 2004, Araújo et al. 2007b, Phan et al. 2007b, Martines-Laso et al. 2008), G1 (Arista et al. 2006), G2 (Arista et al. 2005, Araújo et al. 2007c), G3 (Phan et al. 2007a) and G4 (Parra et al. 2008), demonstrating the complex molecular epidemiology of these pathogens. In this context, the immunogenicity and efficacy of RV-A vaccines may be challenged by evolution of the RV-A viral genome. Besides VP4 and VP7 binary classification, sequence analyses have revealed the existence of several distinct NSP4 genotypes: A (KUN), B (Wa), C (AU-1), D (EW) and E (avian-like) (Tavares et al. 2008). In this context, NSP4 typing of RV-A-positive samples collected in Centralwestern and Southeastern Brazil showed the predominance of genotype B (Araújo et al. 2007b, Tavares et al. 2008). Recently, Matthijnssens et al. (2008) proposed a new classification system for $\mathrm{RV}-\mathrm{A}$, based on the molecular properties of all $11 \mathrm{RV}-\mathrm{A}$ gene segments. Phylogenetic analyses suggest that the molecular characteristics of $V P 1, V P 2, V P 3, V P 6, N S P 1$, $N S P 2, N S P 3, N S P 4$ and NSP5 genes result in 4, 5, 6, 11, $14,5,7,11$ and 6 genotypes, respectively. These authors propose that this novel genotyping classification system allows for a more systematic approach for investigation of possible genetic linkages among RV-A genome segments. In addition, this system revealed a possible animal origin for the most common human RV-A strains, pointing to the need for simultaneous analysis of animal and human RV-A strains. These findings reemphasize the complexity of RV-A taxonomy, posing new issues to the surveillance programs that should be implemented in the RV-A post-vaccination era, in an attempt to answer remaining questions related to the worldwide distribution of RV-A genotypes as well as the potential for both reassortments and emergence of genotypes.
Viral genome detection in environmental samples, including freshwater bodies in many hydrographic networks could contribute to characterizing the RV-A burden in several geographic settings and could be performed simultaneously with hospital-based RV-A surveillance (Miagostovich et al. 2008), looking for additional changes in the post-vaccination era.

\section{ACKNOWLEDGEMENTS}

To several colleagues which have worked over the last 20 years with rotavirus characterization in Brazil.

\section{REFERENCES}

Amarilla A, Espínola EE, Galeano ME, Fariña N, Russomando G, Parra GI 2007. Rotavirus infection in the Paraguayan population from 2004 to 2005: high incidence of rotavirus strains with short electropherotype in children and adults. Med Sci Monit 13: CR333-337.

Andreasi MS, Batista SM, Tozetti IA, Ozaki CO, Nogueira MM, Fiaccadori FS, Borges AM, Santos RA, Cardoso DD 2007. Rotavirus $A$ among hospitalized infants, up to three years of age, with acute gastroenteritis in Campo Grande, state of Mato Grosso do Sul. Rev Soc Bras Med Trop 40: 411-414.

Andreasi MS, Cardoso DD, Fernandes SM, Tozetti IA, Borges AM, Fiaccadori FS, Santos RA, Souza M 2008. Adenovirus, calicivirus and astrovirus detection in fecal samples of hospitalized children with acute gastroenteritis from Campo Grande, MS, Brazil. Mem Inst Oswaldo Cruz 103: 741-744.

Araújo IT, Assis RM, Fialho AM, Mascarenhas JD, Heinemann MB, Leite JP 2007a. Brazilian P[8], G1, P[8], G5, P[8], G9 and P[4], G2 rotavirus strains: nucleotide sequence and phylogenetic analysis. J Med Virol 79: 995-1001.

Araújo IT, Ferreira MS, Fialho AM, Assis RM, Cruz CM, Rocha M, Leite JP 2001. Rotavirus genotypes P[4]G9, P[6]G9 and P[8]G9 in hospitalized children with acute gastroenteritis in Rio de Janeiro, Brazil. J Clin Microbiol 39: 1999-2001.

Araújo IT, Fialho AM, de Assis RM, Rocha M, Galvão M, Cruz CM, Ferreira MS, Leite JP 2002. Rotavirus strain diversity in Rio de Janeiro, Brazil: characterization of VP4 and VP7 genotypes in hospitalized children. J Trop Pediatr 48: 214-218.

Araújo IT, Heinemann MB, Mascarenhas JDAP, Assis RMS, Fialho AM, Leite JPG 2007b. Molecular analysis of the NSP4 and VP6 genes of rotavirus strains recovered from hospitalized children in Rio de Janeiro, Brazil. J Med Microbiol 56: 854-859.

Araújo TME, Dantas JM, Carvalho CEF, Costa MAO 2007c. Surto de diarréia por rotavirus no município de Bom Jesus/PI. Available from: http://www.abrasco.org.br/cienciaesaudecoletiva/artigos/artigo_int.php?id_artigo=1166 [2008 Ago 12].

Arista S, Giammanco GM, De Grazia S, Colomba C, Martella V, Cascio A, Iturriza-Gòmara M 2005. G2 rotavirus infections in an infantile population of the South of Italy: variability of viral strains over time. J Med Virol 77: 587-594.

Arista S, Giammanco GM, De Grazia S, Ramirez S, Lo Biundo C, Colomba C, Cascio A, Martella V 2006. Heterogeneity and temporal dynamics of evolution of G1 human rotaviruses in a settled population. J Virol 80: 10724-10733.

Arista S, Giovannelli L, Pistoia D, Cascio A, Parea M, Gerna G 1990. Electropherotypes, subgroups and serotypes of human rotavirus strains causing gastroenteritis in infants and young children in Palermo, Italy, from 1985 to 1989. Res Virol 141: 435-448. 
Barnes GL, Uren E, Stevens KB, Bishop RF 1998. Etiology of acute gastroenteritis in hospitalized children in Melbourne, Australia, from April 1980 to March 1993. J Clin Microbiol 36: 133-138.

Bernstein DI, Sander DS, Smith VE, Schiff GM, Ward RL 1991. Protection from rotavirus reinfection: 2-year prospective study. $J$ Infect Dis 164: 277-283.

Bhan MK, Lew JF, Sazawal S, Das BK, Gentsch JR, Glass RI 1993. Protection conferred by neonatal rotavirus infection against subsequent rotavirus diarrhea. J Infect Dis 168: 282-287.

Bishop RF, Barnes GL, Cipriani E, Lund JS 1983. Clinical immunity after neonatal rotavirus infection. A prospective longitudinal study in young children. $N$ Engl J Med 309: 72-76.

Bishop RF, Unicomb LE, Barnes GL 1991. Epidemiology of rotavirus serotypes in Melbourne, Australia, from 1973 to 1989. J Clin Microbiol 29: 862-868.

Boschi-Pinto C, Velebit L, Shibuya K 2008. Estimating child mortality due to diarrhoea in developing countries. Available from: http:// www.who.int/bulletin/volumes/86/9/07-050054/en/print.html.

Cardoso das D, Soares CM, Azevedo MS, Leite JP, Munford V, Racz ML 2000. Serotypes and subgroups of rotavirus isolated from children in central Brazil. J Health Popul Nutr 18: 39-43.

Cardoso DDP, Rácz ML, Azevedo MSP, Martins RMB, Soares CMA 2001. Genotyping of group A rotavirus samples from Brazilian children by probe hybridization. Braz J Med Biol Research 34: 471-473.

Carmona RC, Timenetsky M do C, da Silva FF, Granato CF 2004. Characterization of rotavirus strains from hospitalized and outpatient children with acute diarrhoea in São Paulo, Brazil. J Med Virol 74: 166-172.

Carmona RC, Timenetsky M do C, Morillo SG, Richtzenhain LJ 2006. Human rotavirus serotype G9, São Paulo, Brazil, 19962003. Emerg Infect Dis 12: 963-968.

Carvalho-Costa FA, Araújo IT, Assis RM, Fialho AM, Bóia MN, Alves DPD, Martins CMMA, Leite JPG 2009. Rotavirus surveillance in Rio de Janeiro, Brazil: changes in genotypes distribution following vaccine implementation. Emerg Infect Dis 15, in press.

Carvalho-Costa FA, Assis RM, Fialho AM, Bóia MN, Alves DPD, Martins CMMA, Leite JPG 2006. Detection and molecular characterization of group A rotavirus from hospitalized children in Rio de Janeiro, Brazil, 2004. Mem Inst Oswaldo Cruz 101: 291-294.

Castello AA, Arvay ML, Glass RI, Gentsch J 2004. Rotavirus strain surveillance in Latin America: a review of the last nine years. Pediatr Infect Dis J 23 (Suppl): S168-S172.

CDC 1999. Withdrawal of rotavirus vaccine recommendation. MMWR 48: 1007.

CDC 2007. Rotavirus vaccines. MMWR 82: 285-296.

CDC 2008. Rotavirus surveillance - worldwide, 2001-2008. MMWR 57: $1255-1257$.

Ciarlet M, Hoffmann C, Lorusso E, Baselga R, Cafiero MA, Bányai K, Matthijnssens J, Parreño V, de Grazia S, Buonavoglia C, Martella V 2008. Genomic characterization of a novel group A lamb rotavirus isolated in Zaragoza, Spain. Virus Genes 37: 250-265.

Costa PSS, Cardoso DPP, Grisi SJFE, Silva AP, Fiaccadori F, Souza MBLD, Rodrigo AT 2004. Rotavirus A infections and reinfections: genotyping and vaccine implications. $J$ Ped (Rio de Janeiro) 80: 119-122.

de Castro L, Rodrigues DP, Flauzino R, Moura M, Leite JP 1994. An outbreak of diarrhoea associated with rotavirus serotype 1 in a day care nursery in Rio de Janeiro, Brazil. Mem Inst Oswaldo Cruz 89: 5-9.

Dennehy PH 2008. Rotavirus vaccines: an overview. Clin Microbiol Rev 21: 198-208. de Oliveira ASL, Mascarenhas JDP, Soares LS, Guerra SFS, Gabbay YB, Sanchez NO, Linhares AC 2008. Reemergence of G2 rotavirus serotypes in Northern Brazil reflects a natural changing pattern over time. The 8th Rotavirus International Symposium, Istanbul, Turkey, Abstracts p. 60-61.

Domingues AL, Morais AT, Cruz RL, Moreira LP, Gouvêa VS 2008. Rotavirus-associated infantile diarrhea in Uberaba, Minas Gerais, on the wake of the Brazilian vaccination program. J Clin Virol 43: 298-301.

Estes MK 2001. Rotaviruses and their replication. In DE Griffin, DM Knipe, PM Howley (eds.), Fields virology, 5th ed., Lippincott Williams \& Wilkins, Philadelphia, p. 1747-1785.

Ferrera A, Quan D, Espinoza F 2007. Increased prevalence of genotype $\mathrm{G} 2 \mathrm{P}(4)$ among children with rotavirus-associated gastroenteritis in Honduras. The 17th European Congress of Clinical Microbiology and Infectious Diseases ICC, Munich, Germany.

Fonteyne J, Zissis G, Lambert JP 1978. Recurrent rotavirus gastroenteritis. Lancet 1: 983.

Friedman MG, Galil A, Sarov B, Margalith M, Katzir G, Midthun K, Taniguchi K, Urasawa S, Kapikian AZ, Edelman R 1988. Two sequential outbreaks of rotavirus gastroenteritis: evidence for symptomatic and asymptomatic reinfections. J Infect Dis 158: 814-822.

Gentsch JR, Laird AR, Bielfelt B, Griffin DD, Banyai K, Ramachandran M, Jain V, Cunliffe NA, Nakagomi O, Kirkwood CD, Fischer TK, Parashar UD, Bresee JS, Jiang B, Glass RI 2005. Serotype diversity and reassortment between human and animal rotavirus strains: implications for rotavirus vaccine programs. J Infect Dis 192 (Suppl): S146-S159.

Georges-Courbot MC, Monges J, Beraud-Cassel AM, Gouandjika I, Georges AJ 1988. Prospective longitudinal study of rotavirus infections in children from birth to two years of age in Central Africa. Ann Inst Pasteur Virol 139: 421-428.

Glass RI, Parashar UD, Bresee JS, Turcios R, Fischer TK, Widdowson MA, Jiang B, Gentsch JR 2006. Rotavirus vaccines: current prospects and future challenges. Lancet 368: 323-332.

Gómara MI, Cubitt D, Desselberger U, Gray J 2001. Amino acid substitution within the VP7 protein of G2 rotavirus strains associated with failure to serotype. J Clin Microbiol 39: 3796-3798.

Gouvea V, de Castro L, Timenetsky MC, Greenberg H, Santos N 1994. Rotavirus serotype G5 associated with diarrhea in Brazilian children. J Clin Microbiol 2: 1408-1409.

Gouvea V, Santos N 1999. Rotavirus serotype G5: an emerging cause of epidemic childhood diarrhea. Vaccine 17: 1291-1292.

Gouvea VS, Domingues ALS, Naveca FG, Pedro AR, Bevilacqua CC 2007. Changing epidemiology of rotavirus-related hospitalizations in Rio De Janeiro, Brazil, from 2002 to 2006. Open J Virol 1: 47-50.

Grimwood K, Kirkwood CD 2008. Human rotavirus vaccines: too early for the strain to tell. Lancet 371: 1144-1145.

Gurgel RQ, Cuevas LE, Vieira SCF, Barros VCF, Fontes PB, Salustino EF, Nakagomi O, Nakagomi T, Dove W, Cunliffe N, Hart CA 2007. Predominance of rotavirus P[4]G2 in a vaccinated population, Brazil. Emerg Infect Dis 13: 1571-1573.

Gurgel RQ, Cunliffe NA, Nakagomi O, Cuevas LE 2008. Rotavirus genotypes circulating in Brazil before national rotavirus vaccination: a review. J Clin Virol 43: 1-8.

Gurwith M, Wenman W, Hinde D, Feltham S, Greenberg H 1981. A prospective study of rotavirus infection in infants and young children. J Infect Dis 144: 218-224. 
Gusmão RH, Mascarenhas JD, Gabbay YB, Lins-Lainson Z, Ramos FL, Monteiro TA, Valente SA, Fagundes-Neto U, Linhares AC 1999. Rotavirus subgroups, G serotypes and electrophoretypes in cases of nosocomial infantile diarrhoea in Belém, Brazil. J Trop Pediatr 45: 81-86.

Gusmão RH, Mascarenhas JD, Gabbay YB, Lins-Lainson Z, Ramos FL, Monteiro TA, Valente SA, Linhares AC 1995. Rotaviruses as a cause of nosocomial, infantile diarrhoea in northern Brazil: pilot study. Mem Inst Oswaldo Cruz 90: 743-749.

Hoshino Y, Jones RW, Ross J, Honma S, Santos N, Gentsch JR, Kapikian AZ 2004. Rotavirus serotype G9 strains belonging to VP7 gene phylogenetic sequence lineage 1 may be more suitable for serotype G9 vaccine candidates than those belonging to lineage 2 or 3. J Virol 78: 7795-7802.

Kale PL, Andreozzi VL, Nobre FF 2004. Time series analysis of deaths due to diarrhoea in children in Rio de Janeiro, Brazil, 1980-1998. J Health Popul Nutr 22: 27-33.

Kapikian AZ, Hoshino Y, Chanock RM 2003. Rotaviruses. In DM Knipe, PM Howley (eds.), Fields Virology, 3rd ed., LippincottRaven Press, Philadelphia, p. 1657-1708.

Leite JP, Alfieri AA, Woods PA, Glass RI, Gentsch JR 1996. Rotavirus $\mathrm{G}$ and $\mathrm{P}$ types circulating in Brazil: characterization by RTPCR, probe hybridization and sequence analysis. Arch Virol 141: 2365-2374.

Linhares AC, Gabbay YB, Mascarenhas JD, Freitas RB, Flewett TH, Beards GM 1988. Epidemiology of rotavirus subgroups and serotypes in Belém, Brazil: a three-year study. Ann Inst Pasteur Virol 139: 89-99.

Linhares AC, Moura JM, Gabbay YB, Mendes PS, Mascarenhas JD, de Azevedo RC 1993. Rotavirus serotypes and electrophoretypes among children attending three paediatric hospitals in Belém, Brazil. J Trop Pediatr 39: 137-141.

Linhares AC, Velázquez FR, Pérez-Schael I, Sáez-Llorens X, Abate H, Espinoza F, López P, Macías-Parra M, Ortega-Barría E, Rivera-Medina DM, Rivera L, Pavía-Ruz N, Nuñez E, Damaso S, Ruiz-Palacios GM, De Vos B, O'Ryan M, Gillard P, Bouckenooghe A, Human Rotavirus Vaccine Study Group 2008. Efficacy and safety of an oral live attenuated human rotavirus vaccine against rotavirus gastroenteritis during the first 2 years of life in Latin American infants: a randomized, double-blind, placebocontrolled phase III study. Lancet 371: 1181-1189.

López S, Espinosa R, Greenberg HB, Arias CF 1994. Mapping the subgroup epitopes of rotavirus protein VP6. Virology 204: 153-162.

Luz CRNE, Mascarenhas JDP, Gabbay YB, Motta ARB, RibeiroLima TV, Soares LS, Linhares AC 2005. Rotavirus serotypes and electropherotypes identified among hospitalized children in São Luís, Maranhão, Brazil. Rev Inst Med Trop S Paulo 47: 287-293.

Macedo CI, Christofoletti A, Munford V, Rácz ML 2007. G and P rotavirus genotypes in stool samples from children in Teresina, state of Piauí. Rev Soc Bras Med Trop 40: 381-384.

Magalhães GF, Nogueira PA, Grava AF, Penati M, Silva LH, Orlandi PP 2007. Rotavirus and adenovirus in Rondônia. Mem Inst Oswaldo Cruz 102: 555-557.

Martinez-Laso J, Román A, Head J, Cervera I, Rodríguez M, Rodríguez-Avial I, Picazo JJ 2008. Phylogeny of G9 rotavirus genotype: a possible explanation of its origin and evolution. $J$ Clin Virol, in press.

Martini IJ, Gennari GM, Martins SS, Gouvêa VS, Gatti MS 2008. Changing distribution of human rotavirus serotypes during two epidemic outbreaks of gastroenteritis in Campinas, São Paulo, Brazil, 2003-2004: detection of G6 strains. J Clin Virol 43: 244-246.
Mascarenhas JD, Gusmao RH, Barardi CR, Paiva FL, Simoes CO, Gabbay YB, Monteiro TA, Linhares AC 1999. Characterization of rotavirus $\mathrm{P}$ genotypes circulating among paediatric inpatients in Northern Brazil. Rev Inst Med Trop São Paulo 41: 165-170.

Mascarenhas JD, Paiva FL, Barardi CR, Gabbay YB, Simoes CO, Linhares AC 1998. Rotavirus $\mathrm{G}$ and $\mathrm{P}$ types in children from Belém, Northern Brazil, as determined by RT-PCR: occurrence of mixed P type infections. J Diarrhoeal Dis Res 16: 8-14.

Mascarenhas JDP, Linhares AC, Gabbay YB, Leite JDP 2002. Detection and characterization of rotavirus $\mathrm{G}$ and $\mathrm{P}$ types from children participating in a rotavirus vaccine trial in Belém, Brazil. Mem Inst Oswaldo Cruz 97: 113-117.

Matthijnssens J, Ciarlet M, Rahman M, Attoui H, Bányai K, Estes MK, Gentsch JR, Iturriza-Gómara M, Kirkwood CD, Martella V, Mertens PP, Nakagomi O, Patton JT, Ruggeri FM, Saif LJ, Santos N, Steyer A, Taniguchi K, Desselberger U, Van Ranst M 2008. Recommendations for the classification of group A rotaviruses using all 11 genomic RNA segments. Arch Virol 153: 1621-1629.

Miagostovich MP, Ferreira FF, Guimarães FR, Fumian TM, DinizMendes L, Luz SL, Silva LA, Leite JP 2008. Molecular detection and characterization of gastroenteritis viruses occurring naturally in the stream waters of Manaus, central Amazonia, Brazil. Appl Environ Microbiol 74: 375-382.

Miller MA, McCann L 2000. Policy analysis of the use of hepatitisB, Haemophilus influenzae, type-B, Streptococcus pneumoniaeconjugated and rotavirus vaccines in national immunization schedules. Health Econ 9: 19-35.

Montenegro FM, Correia JB, Rodrigues Falbo A, Dove W, Nakagomi T, Nakagomi O, Cuevas LE, Cunliffe NA, Hart CA 2007. Anticipating rotavirus vaccines in Brazil: detection and molecular characterization of emerging rotavirus serotypes G8 and G9 among children with diarrhoea in Recife, Brazil. J Med Virol 79: 335-340.

Moulton LH, Staat MA, Santosham M, Ward RL 1998. The protective effectiveness of natural rotavirus infection in an American Indian population. J Infect Dis 178: 1562-1566.

MS - Ministério da Saúde 2006. DATASUS. Available from: http:// tabnet.datasus.gov.br/cgi/deftohtm.exe?idb2006/c07.def.

Nakagomi T, Cuevas LE, Gurgel RG, Elrokhsi SH, Belkhir YA, Abugalia M, Dove W, Montenegro FM, Correia JB, Nakagomi O, Cunliffe NA, Hart CA 2008. Apparent extinction of non-G2 rotavirus strains from circulation in Recife, Brazil, after the introduction of rotavirus vaccine. Arch Virol 153: 591-593.

Parashar UD, Gibson CJ, Bresee JS, Glass RI 2006. Rotavirus and severe childhood diarrhea. Emerg Infect Dis 12: 304-306.

Parra GI, Vidales G, Gomez JA, Fernandez FM, Parreño V, Bok K 2008. Phylogenetic analysis of porcine rotavirus in Argentina: increasing diversity of G4 strains and evidence of interspecies transmission. Vet Microbiol 126: 243-250.

Patel MM, de Oliveira LH, Bispo AM, Gentsch J, Parashar UD 2008. Rotavirus P[4]G2 in a vaccinated population, Brazil. Emerg Infect Dis 14: 863-865.

Phan TG, Khamrin P, Quang TD, Dey SK, Takanashi S, Okitsu S, Maneekarn N, Ushijima H 2007a. Detection and genetic characterization of group A rotavirus strains circulating among children with acute gastroenteritis in Japan. J Virol 81: 4645-4653.

Phan TG, Okitsu S, Maneekarn N, Ushijima H 2007b. Genetic heterogeneity, evolution and recombination in emerging G9 rotaviruses. Infect Genet Evol 7: 656-663.

Pietruchinski E, Benati F, Lauretti F, Kisielius J, Ueda M, Volotão EM, Soares CC, Hoshino Y, Linhares RE, Nozawa C, Santos N 2006. Rotavirus diarrhea in children and adults in a southern city 
of Brazil in 2003: distribution of G/P types and finding of a rare G12 strain. J Med Virol 78: 1241-1249.

Rahman M, Sultana R, Ahmed G, Nahar S, Hassan ZM, Saiada F, Podder G, Faruque AS, Siddique AK, Sack DA, Matthijnssens J, Van Ranst M, Azim T 2007. Prevalence of G2P[4] and G12P[6] rotavirus, Bangladesh. Emerg Infect Dis 13: 18-24.

Reves RR, Hossain MM, Midthun K, Kapikian AZ, Naguib T, Zaki AM, DuPont HL 1989. An observational study of naturally acquired immunity to rotaviral diarrhea in a cohort of 363 Egyptian children. Calculation of risk for second episodes using age-specific person-years of observation. Am J Epidemiol 130: 981-988.

Ribeiro LR, Giuberti RS, Barreira DM, Saick KW, Leite JP, Miagostovich MP, Spano LC 2008. Hospitalization due to norovirus and genotypes of rotavirus in pediatric patients, state of Espírito Santo. Mem Inst Oswaldo Cruz 103: 201-206.

Rosa e Silva ML, Pires De Carvalho I, Gouvea V 2002. 1998-1999 rotavirus seasons in Juiz de Fora, Minas Gerais, Brazil: detection of an unusual G3P[4] epidemic strain. J Clin Microbiol 40: 2837-2842.

Ruiz-Palacios GM, Perez-Schael I, Velazquez FR, Abate H, Breuer T, Clemens SC, Cheuvart B, Espinoza F, Gillard P, Innis BL, Cervantes Y, Linhares AC, Lopez P, Macias-Parra M, Ortega-Barria E, Richardson V, Rivera-Medina DM, Rivera L, Salinas B, PaviaRuz N, Salmeron J, Ruttimann R, Tinoco JC, Rubio P, Nunez E, Guerrero ML, Yarzabal JP, Damaso S, Tornieporth N, SaezLlorens X, Vergara RF, Vesikari T, Bouckenooghe A, Clemens R, De Vos B, O’Ryan M, Human Rotavirus Vaccine Study Group 2006. Safety and efficacy of an attenuated vaccine against severe rotavirus gastroenteritis. $N$ Engl J Med 354: 11-22.

Santos N, Hoshino Y 2005a. Global distribution of rotavirus serotypes/ genotypes and its implication for the development and implementation of an effective rotavirus vaccine. Rev Med Virol 15: 29-56.

Santos N, Lima RC, Pereira CF, Gouvea V 1998. Detection of rotavirus types $\mathrm{G} 8$ and $\mathrm{G} 10$ among Brazilian children with diarrhea. $J$ Clin Microbiol 36: 2727-2729.

Santos N, Soares CC, Volotão EM, Albuquerque MCM, Hoshino Y 2003. Surveillance of Rotavirus Strains in Rio de Janeiro, Brazil, from 1997 to 1999. J Clin Microbiol 41: 3399-3402.

Santos N, Volotão EM, Soares CC, Albuquerque MCM, Silva FM, Carvalho TRB, Pereira CFA, Chizhikov V, Hoshino Y 2001. Rotavirus strains bearing genotype $\mathrm{G} 9$ or $\mathrm{P}$ [9] recovered from Brazilian children with diarrhea from 1997 to 1999. J Clin Microbiol 39: $1157-1160$

Santos N, Volotão EM, Soares CC, Campos GS, Sardi SI, Hoshino Y 2005b. Predominance of rotavirus genotype G9 during the 1999, 2000 and 2002 seasons among hospitalized children in the city of Salvador, Bahia, Brazil: implications for future vaccine strategies. J Clin Microbiol 43: 4064-4069.
Souza MB, Racz ML, Leite JP, Soares CM, Martins RM, Munford V, Cardoso DD 2003. Molecular and serological characterization of group A rotavirus isolates obtained from hospitalized children in Goiânia, Brazil, 1998-2000. Eur J Clin Microbiol Infect Dis 22: 441-443.

Stewien KE, Mehnert DU, Hársi CM, Stewien ET, Candeias JM, Tanaka K 1994. Serotypes and electropherotypes of human rotavirus detected in the city of São Luís (MA), Brazil. Braz JMed Biol Res 27: 1355-1361.

Tang B, Gilbert JM, Matsui SM, Greenberg HB 1997. Comparison of the rotavirus gene 6 from different species by sequence analysis and localization of subgroup-specific epitopes using site-directed mutagenesis. Virology 237: 89-96.

Tavares TM, Brito WMED, Fiaccadori FS, Freitas ERL, Parente JA, Costa PSS, Giugliano LG, Andreasi MAS, Soares CMA, Cardoso DDP 2008. Molecular characterization of the NSP4 gene of human group A rotavirus samples from the West Central region of Brazil. Mem Inst Oswaldo Cruz 103: 288-294.

Timenetsky M do C, Santos N, Gouvea V 1994. Survey of rotavirus G and $\mathrm{P}$ types associated with human gastroenteritis in São Paulo, Brazil, from 1986 to 1992. J Clin Microbiol 32: 2622-2624.

Velazquez FR, Matson DO, Calva JJ, Guerrero L, Morrow AL, Carter-Campbell S, Glass RI, Estes MK, Pickering LK, Ruiz-Palacios GM 1996. Rotavirus infections in infants as protection against subsequent infections. N Engl J Med 335: 1022-1028.

Vesikari T, Karvonen A, Prymula R, Schuster V, Tejedor JC, Cohen R, Meurice F, Han HH, Damaso S, Bouckenooghe A 2007. Efficacy of human rotavirus vaccine against rotavirus gastroenteritis during the first 2 years of life in European infants: randomised, double-blind controlled study. Lancet 370: 1757-1763.

Victoria M, Carvalho-Costa FA, Heinemann MB, Leite JP, Miagostovich M 2007a. Genotypes and molecular epidemiology of human astroviruses in hospitalized children with acute gastroenteritis in Rio de Janeiro, Brazil. J Med Virol 79: 939-944.

Victoria M, Carvalho-Costa FA, Heinemann MB, Leite JP, Miagostovich M 2007b. Prevalence and molecular epidemiology of noroviruses in hospitalized children with acute gastroenteritis in Rio de Janeiro, Brazil, 2004. Pediatr Infect Dis J 26: 602-606.

Volotão EM, Soares CC, Maranhão AG, Rocha LN, Hoshino Y, Santos N 2006. Rotavirus surveillance in the city of Rio de Janeiro-Brazil during 2000-2004: detection of unusual strains with G8P[4] or G10P[9] specificities. J Med Virol 78: 263-272.

Ward RL, Bernstein DI 1994. Protection against rotavirus disease after natural rotavirus infection. US Rotavirus Vaccine Efficacy Group. J Infect Dis 169: 900-904.

WHO 2002. Generic protocol for hospital-based surveillance to estimate the burden of rotavirus gastroenteritis in children under 5 years of age. Available from: www.who.int/vaccines-documents/. 